\title{
TOPENG BALI DAN MADURA SEBAGAI SUMBER INSPIRASI PENCIPTAAN TARI (SEBUAH TRADISI, TRANSFORMASI BENTUK DAN FUNGSI)
}

\author{
Endang Sutiyati ${ }^{1}$, Wenti Nuryani ${ }^{1}$, Bambang Setiyo Hari Purwoko ${ }^{2}$ \\ ${ }^{1}$ Fakultas Bahasa dan Seni Universitas Negeri Yogyakarta \\ ${ }^{2}$ Fakultas Teknik Universitas Negeri Yogyakarta \\ E-mail: e.sutiyati@yahoo.co.id
}

\begin{abstract}
Abstrak: Topeng Bali dan Madura Sebagai Sumber Inspirasi Penciptaan Tari (Sebuah Tradisi, Transformasi Bentuk dan Fungsi). Penelitian ini bertujuan untuk menghasilkan (1) deskripsi naratif tentang karakter Topeng Bidadari dari Bali dan Madura; (2) karya tari kreasi baru yang sumber penciptaannya terinspirasi deskripsi naratif dari karakter topeng Bidadari dan topeng Drupadi. Penelitian ini dilakukan dengan menggunakan metode penelitian dan pengembangan (R\&D). Objek penelitian ini adalah bentuk-bentuk gerakan tari. Subjek penelitian adalah ahli tari Bali dan ahli tari Madura. Data penelitian dikumpulkan dengan observasi. Analisis data dilakukan dengan teknik analisis deskriptif kualitatif. Hasil penelitian menunjukkan bahwa pose ragam gerak tari dan penggabungan gerak menjadi sebuah rangkaian gerak tari kreasi baru telah dapat diwujudkan. Pose-pose gerak tari yang telah mengalami distorsi dan abstraksi dari sumber inspirasi, rangkaian gerak tari dalam karya tari hasil pengembangan, disain kostum tari, dan disain iringannya telah sesuai dengan karakter topeng yang menjadi sumber inspirasi penciptaan. Topeng pada awalnya dibuat untuk pemujaan pada roh nenek moyang, kemudian berkembang sebagai bagian dari piranti tari yang disesuaikan dengan karakter tokoh yang dilakonkan penari, kini karakter topeng dapat sebagai sumber penciptaan karya tari.
\end{abstract}

Kata kunci: penciptaan tari, sumber inspirasi, topeng

\begin{abstract}
The Mask of Bali and Madura as a Inspiration Source of Dance Creation (A Tradition, Form Transformation and Function). This study was aimed at (1) describing in a narrative description about the character of Topeng Bidadari (Angel Mask) from Bali, and Madura; (2) producing a new creation dance style which is inspired by the narative description as the creation sourced from the characters of Topeng Bidadari and Topeng Baladewa. This study was used R\&D model. The objects of this study were forms of dance movements. The subjects of the study were Balinese and Madura dance experts. The data were collected through observation. Then, the data were analyzed using qualitative descriptive analysis techniques. The results shows that the form of a variety of dance poses and the incorporation of motion into a series of new creative dance movement have been realized. From the results of the assessment, the Balinese Dance and Madura Dance experts had known that poses in dance movement which had been distorted and abstracted, a series of movements in the dance of the development process, costume designs, and songs in accordance with the design of the mask character are become the source of inspiration for the creation itself. Masks were originally made to worship the spirits of ancestors, then developed as part of a dance device adapted to the character that is played by dancer, now a mask character can be a source of dance creation.
\end{abstract}

Keywords: a source of inspiration, creation dance, mask 


\section{PENDAHULUAN}

Topeng tradisional dibuat sedemikian teliti, indah dan unik oleh para senimannya, dikerjakan dengan hanya mengandalkan kecakapan dan keterampilan tangan, yang dibarengi konsentrasi sangat tinggi dan keinginan kuat untuk tercapainya kepuasan lahir batin sesuai tuntutan jiwa. Pembuatan topeng disikapi sebagai pengabdian yang total pada leluhur mereka.

Setelah sebagai sarana pemujaan, topeng kemudian berkembang sebagai bagian dari piranti tari, yang di dalam menarikannya harus disesuaikan dengan karakter tokoh-tokoh tertentu yang sedang dilakonkan oleh penari. Sejalan dengan perkembangan ilmu pengetahuan, teknologi dan perekonomian masyarakat, maka berubah pula pola pikir, perilaku dan kebutuhan estetik manusia.

Karya topeng kini juga telah mengalami evolusi, berubah fungsi tidak lagi sebagai sarana pemujaan dan piranti tari, akan tetapi menjadi lebih dimaknai sebagai karya seni, yang lahir sebagai bentuk ekspresi seni yang bentuk dan guratan wajahnya menggambarkan karakter tertentu dari manusia.

Bentuk dan guratan wajah dalam karya seni topeng serta karakter yang tersimpan di balik guratan wajah topeng inilah yang menjadi salah satu pendorong bagi peneliti untuk mencoba membuat eksperimen karya cipta seni tari dengan topeng tradisional Bali dan Madura sebagai sumber inspirasi pencip-taannya. Bentuk dan guratan wajah topeng yang menjadi sumber inspirasi peneliti adalah topeng dari daerah Bali dan Madura.

Topeng dari daerah tersebut begitu unik, sangat menarik untuk dinikmati, khususnya pada jenis hiasannya atau ornamennya. Topeng dari Bali memiliki banyak simbol dengan asesoris yang unik, baik yang terbuat dari kayu, kain, kaca, maupun kulit. Pernik-pernik ornamen inilah yang menjadi gagasan ide bagi peneliti untuk melakukan penelitian penciptaan tari.

Proses penciptaan yang dilakukan adalah mengolah penafsiran bentuk muka, guratan wajah topeng menjadi deskripsi naratif, yang kemudian dikembangkan, didistorsi, serta diabstraksikan sehingga menjadi gerak tari dan kostum sebagai suatu karya seni yang berdiri sendiri lepas dari fungsi awalnya, baik sebagai penutup wajah maupun sebagai alat ritual.

Tujuan penelitian untuk penciptaan karya seni tari ini adalah (1) membuat atau menghasilkan deskripsi naratif karakter topeng Bidadari dari Bali, dan Madura sebagai sumber penciptaan tari. (2) Menghasilkan bentuk pose-pose dan rangkaian gerakan tari yang merupakan terjemahan dari karakter yang tersimpan di balik wajah topeng Bidadari menjadi sebuah karya tari kreasi baru yang dapat diterima oleh masyarakat

Penafsiran terhadap karakter wajah topeng dapat dilakukan melalui kajian fenomenologis. Fenomenologi merupakan kajian tentang bagaimana manusia sebagai subjek memaknai objek-objek di sekitarnya. Melalui teori fenomenologi peneliti akan mengungkapkan berbagai pengkajian terkait karya seni topeng yang ada di Bali dan Madura serta bagaimana upaya yang akan dilakukan agar topeng tersebut tetap konsen jadi bahan ide.

Karakter wajah topeng juga dapat ditafsirkan menggunakan teori inovasi. Suatu inovasi merupakan suatu proses pembaruan karena munculnya penemuan baru. Suatu penemuan biasanya melalui dua tahapan khusus, yaitu discovery dan invention. Discovery adalah suatu penemuan dari suatu unsur kebudayaan yang baru, baik berupa suatu alat baru atau ide baru yang diciptakan oleh seseorang individu maupun kelompok 
dalam masyarakat yang bersangkutan. Proses discovery menjadi invention apabila masyarakat sudah mengakui, menerima, dan menerapkan penemuan baru tersebut (Koentjaraningrat, 1990: 256-258).

Topeng berarti penutup muka yang terbuat dari kayu, kertas, kain atau bahan lainnya dengan bentuk yang berbedabeda. Penutup muka tersebut memiliki bentuk bermacam-macam, mulai dari yang berbentuk wajah dewa-dewi, manusia, binatang, setan dan lain-lainnya. Topeng adalah benda yang dipakai di atas wajah.

Biasanya topeng dipakai untuk mengiringi musik kesenian daerah. Topeng sebagai kesenian daerah umumnya dipakai untuk menghormati sesembahan atau memperjelas watak dalam mengiringi kesenian. Bentuk topeng memiliki mimik muka bermacam-macam, ada mimik yang menggambarkan watak atau mimik marah, ada yang menggambarkan kelembutan, dan ada pula yang menggambarkan kebijaksanaan.

Topeng awalnya merupakan alat upacara tradisional yang dimiliki oleh berbagai daerah di Indonesia, termasuk juga di Madura. Seni Topeng, khususnya topeng dalang sudah dikenal luas di Madura sejak abad XV-XVI. Sejalan dengan perkembangan zaman, topeng tidak lagi hanya sebagai sarana ritual upacara agama akan tetapi sat ini topeng juga dapat digunakan sebagai piranti menari.

Sebagai piranti menari, maka penari harus membawakan tariannya agar sesuai dengan karakter wajah topeng yang dikenakannya. Karakter wajah suatu topeng dapat dideskripsikan melalui makna dari simbol-simbol yang ada pada topeng tersebut. Simbolis warna topeng Madura tidak jauh berbeda dengan simbolis warna topeng Jawa. Tokoh ksatria yang paling utama dalam topeng Madura seperti Rama, Arjuna dan tokoh Panji wajahnya diberi warna dasar hijau.
Karena Rama dan Arjuna adalah symbol bayangan insani, yang senantiasa berusaha mencapai tujuan hidup lestari, selalu dijalan yang benar.

Tokoh Dewi Sinta, Dewi Sembodro di Madura dan Dewi Candrakirana di Jawa yang melambangkan tujuan hidup diberi warna dasar keemasan. Warna itu merupakan ungkapan kemuliaan hidup dalam bentuk materi (emas). Tokoh Semar merupakan tokoh suci, melambangkan kewaskitaan, kesetiaan dalam mengabdikan diri kepada keadilan dan kebenaran, diberi warna putih. Demikian juga Dewi Srikandi, Dewi Drupadi yang melambangkan kesucian wanita. Warna merah pun tak ketinggalan, mendominasi warna-warna topeng Madura. Topeng yang berwajah merah terdiri dari tokoh ksatria atau raja yang bertubuh gagah perkasa, dan juga para raksasa.

Selain warna dasar, ada unsur lain yang secara efektif sangat membantu gambaran perwatakan pada topeng Madura, yaitu bentuk mata dan bentuk batang hidung. Khusus mengenai bentuk mata dan bentuk batang hidung ini sangatlah membantu dalam membuat/ menciptakan mimik (raut wajah) tokoh sesuai dengan karakter/watak dari tokoh tersebut. Ada beberapa bentuk mata yang dikenal: bentuk mata gabahan (watak mulia), bentuk mata telengan (wajah yang tangguh), bentuk mata plelangan (perkasa tapi keji), bentuk mata kelipan (arif bijaksana), bentuk mata penanggalan (perangai culas, curang tapi cerdas).

Proses penciptaan tari dapat dilakukan menggunakan beberapa acuan dasar, di antaranya: (1) pengetahuan tentang topeng di berbagai Negara dan di Indonesia, terutama Topeng Bali dan Topeng Madura; (2) bentuk-bentuk simbol ekspresif seni yang bervariasi (diferensiasi), dan fenomena sosio- 
kultural pada masyarakat pendukungnya (inkulturasi) bagaimana dapat diolah menjadi suatu karya seni; (3) cara/ teknik pembuatan tari dan analisisnya (dance analysis theory and practice); dan (4) pendekatan-pendekatan seni dan sejarah.

\section{METODE}

Penelitian penciptaan tari ini dilakukan mengikuti langkah-langkah metode penelitian dan pengembangan (Reseacrh and Development/R\&D). Penelitian ini diawali dengan studi pendahuluan. Penelitian awal ini menghasilkan deskripsi naratif karakter topeng, yang selanjutnya akan digunakan sebagai acuan untuk penciptaan gerak tari. Desain penelitian ditunjukkan Gambar 1 dan langkah penciptaan tari disajikan pada Gambar 2.

Desain dalam penelitian ini mengikuti desain/prosedur penelitian dan pengembangan yang disampaikan oleh Borg \& Gall (1983) yang terdiri dari empat tahap, yaitu define, design, develop, dan dessemination.

Konsep yang menjadi dasar pengembangan produk ini adalah teori bahwa tari merupakan bentuk ekspresi yang selain makna ekspresinya dapat dipersepsi oleh masyarakat juga sarat akan estetika yang memberi rasa keindahan bagi yang menyaksikan. Desain produk mengacu pada konsep bahwa tari adalah gabungan antara gerak, iringan, dan busana tari atau kostum. Karya tari mempunyai struktur berupa tampilan fisik gerak tari yang mampu menggambarkan karakter topeng sesuai dengan deskripsi naratif yang menjadi sumber inspirasi penciptaan. Tampilan fisik karya tari ini digolongkan menjadi gerakan tari dan tata rias penari dan busana (kostum).

Gerakan tari adalah bagian terbesar yang mengekspresikan karakter tokoh yang sedang dijalankan penari, misalnya tokoh yang lembut, kasar, marah, dan sebagainya. Tata rias merupakan aspek

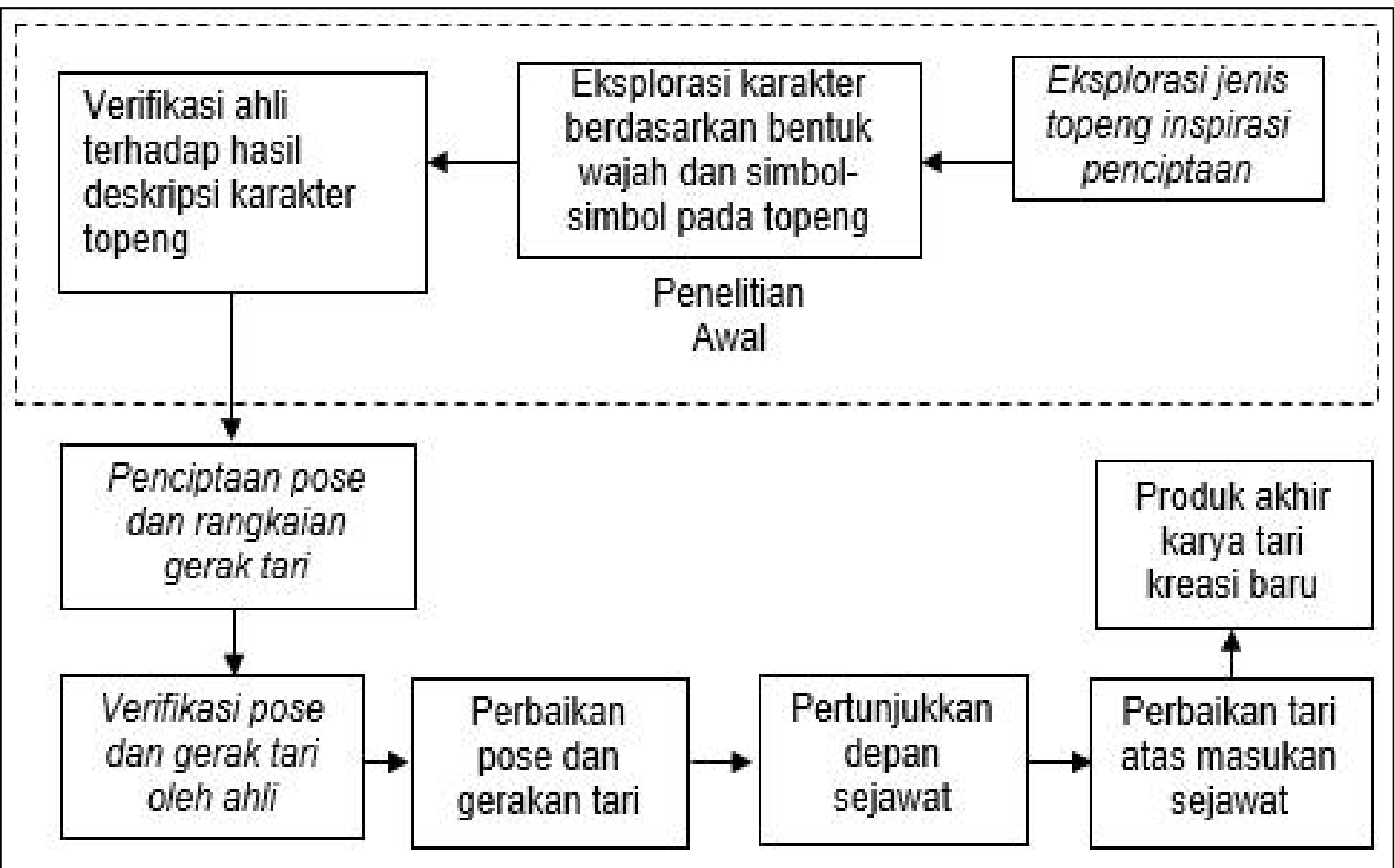

Gambar 1. Desain Penelitian 


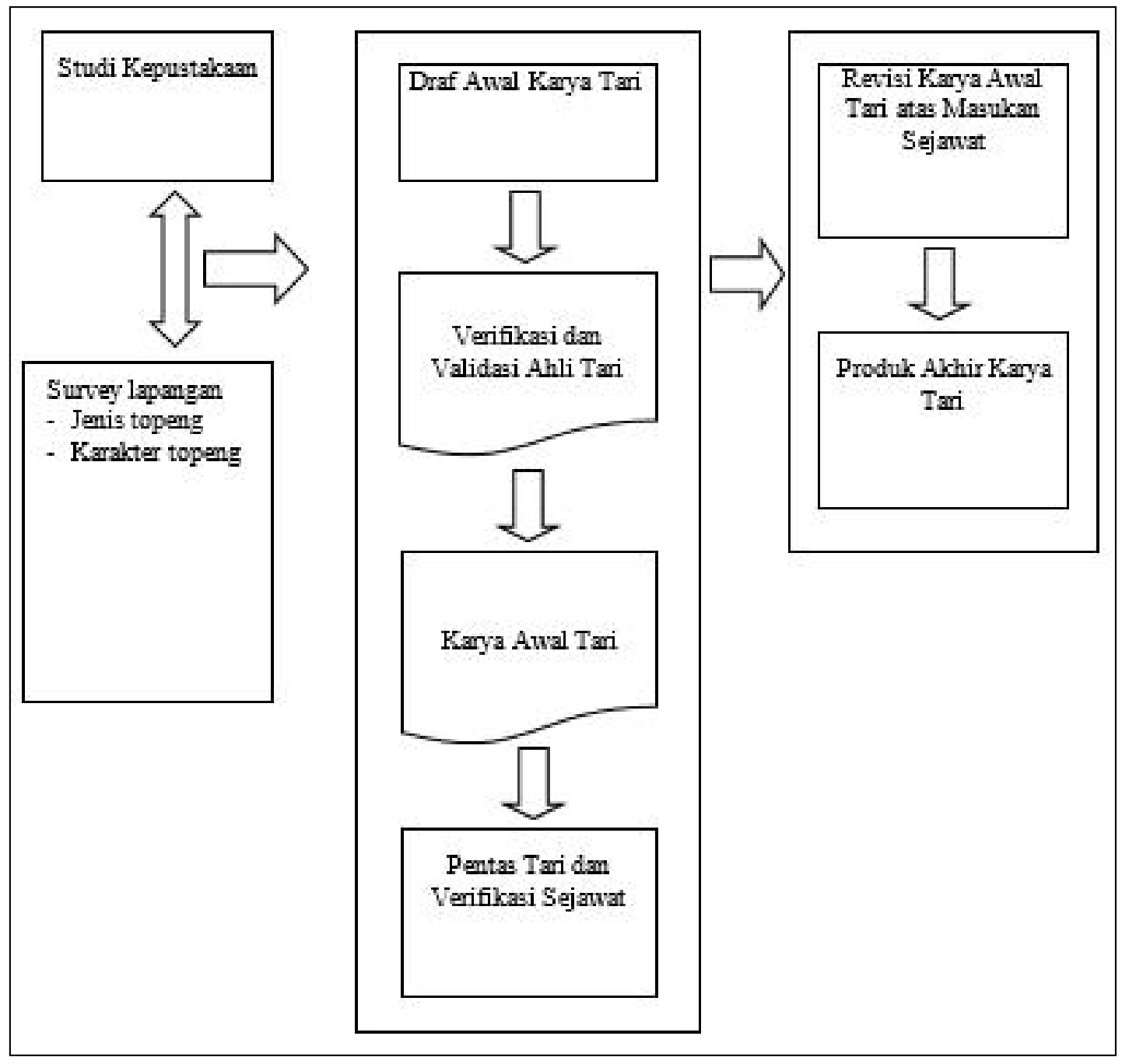

Gambar 2. Langkah-langkah Penciptaan Tari

pendukung untuk dapat menciptakan karakter sesuai tokoh yang diinginkan.

Busana tari merupakan asesoris, yang dapat mendukung pencerminan karakter penari. Busana, disamping harus kaya warna melambangkan kebesaran, tetapi juga harus selektif agar indah, dan serasi.

Verifikasi untuk melihat sejauh mana keberhasilan karya tari yang dibuat dapat memenuhi tujuan dilakukan dalam beberapa tahapan, sesuai dengan tahapan pengembangan karya tari. Tahapan tersebut mencakup verifikasi draf awal oleh ahli tari dari Bali dan tari Madura, sedang- kan verifikasi karya awal dilakukan oleh sejawat pengajar tari. Verifikasi draf awal dilakukan untuk mengetahui apakah posepose yang dibuat sudah mencerminkan karakter yang dideskripsikan dalam hasil penelitian pendahuluan. Verifikasi karya awal dilakukan untuk melihat keseluruhan rangkaian gerak tari, keserasian busana (kostum), dan iringan, dengan karakter topeng yang dideskripsikan.

Obyek dalam penelitian ini adalah karakter keseluruhan gerak tari, busana, dan iringan. Penelitian ini dilakukan untuk menghasilkan karya tari yang diilhami oleh karakter topeng. Obyek penelitian 
dalam penelitian ini dapat dilihat pada Tabel 1.

Subjek dalam penelitian penciptaan tari adalah para ahli yang menjadi sumber data pada penelitian (studi) pendahuluan, dan para ahli yang melakukan verifikasi draf awal, karya awal. dan karya akhir tari. Subjek penelitian (sumber data) tersebut adalah pakar tari Bali, pakar tari Madura, pengajar seni tari, peñata kostum tari, dan penata iringan.

Data dalam penelitian ini dikumpulkan dengan metode obsevasi dan dokumentasi. Alat untuk pengumpulan data pada studi pendahuluan adalah lembar observasi. Alat pengumpul data saat verifikasi produk adalah lembar observasi, dan kuisioner.

Pengumpulan data dilakukan dengan verifikasi ahli (Expert Jugment). Verifikasi Ahli bertujuan untuk mereview gerak tari yang dikembangkan dan juga sebagai validasi awal apakah gerak tari tersebut telah sesuai dengan karakter yang diinginkan. Pengujian ahli ini dilakukan untuk mengetahui harmonisasi gerak, keseimbangan gerak (balance), kekuatan gerak, ritme gerak, dan volume gerak. Pengujian dilakukan oleh ahli tari Bali dan ahli tari Madura.

Teknik analisis data hasil verifikasi terhadap draf awal, dan karya awal sehingga menjadi karya akhir seni tari dilakukan menggunakan teknik statistik deskriptif kualitatif.

\section{HASIL DAN PEMBAHASAN}

Studi pendahuluan dalam penelitian ini adalah mengembangkan rangsang awal, yaitu menghadirkan rangsang yang membangkitkan fikir, semangat atau mendorong kegiatan. Kemunculan ide garapan dan ide gerak terbentuk karena rangsangan.

Rangsang awal dalam garap karya tari ini adalah (1) rangsang gagasan dengan melihat rangkaian prosesi pertunjukan tari sakral di Bali dan tari di Madura. Selain berdasarkan pengamatan langsung yakni dengan melihat pagelaran dan festival tari yang ada di daerah tersebut peneliti juga mengapresiasi dari video tari baik tradisi maupun kreasi. (2) Rangsang kinestetik, yaitu hasil dari menangkap suatu kesan dari gejala gerak berikut rasa geraknya (kinestetik).

Rangsang ini didapat ketika peneliti berinisiatif untuk mengembangkan bentuk dasar gerak tari daerah Bali dan Madura menjadi sebuah pengembangan gerak yang inovatif. Gerakan ini kemudian dikembangkan dan dikombinasikan dengan gerakan tari daerah lain yaitu Jawa. Proses yang dilakukan dalam penelitian penciptaan tari antara lain sebagai berikut.

Tabel 1. Objek Penelitian Penciptaan Tari

\begin{tabular}{ll}
\hline \multicolumn{1}{c}{ Jenis Verifikasi } & \multicolumn{1}{c}{ Obyek Penelitian } \\
\hline Karakter Gerak Tari & 1. Karakter gerak maknawi \\
& 2. Karakter gerak murni \\
& 3. Karakter gerak distorsi \\
& 4. Karakter gerak abstraksi \\
Kostum dan Asesoris & 1. Keserasian kostum dengan karakter dalam deskripsi \\
& 2. Keserasian Asesoris dengan karakter dalam deskripsi \\
Iringan & Kesesuaian Iringan dengan karakter dalam deskripsi \\
\hline
\end{tabular}


Eksplorasi. Topeng Bali dan topeng Madura yang menjadi sumber inspirasi penciptaan tari ini, oleh tim peneliti diamati secara mendalam agar dapat mendapatkan makna karakternya. Karakter topeng coba diungkapkan dengan membuat deskripsi naratif mengenai karakter topeng tersebut. Langkah selanjutnya adalah proses pencarian tema dan proses menentukan konsep koreografi sebagai dasar atau pijakan pembuatan karya tari.

Berdasarkan konsep koreografi yang ditentukan dimulailah proses pencarian gerak. Pencarian gerak dilakukan melalui eksplorasi, yaitu aktivitas untuk mencoba-coba melalui kreativitasnya, peneliti melakukan berbagai ragam gerak, mengumpulkan ragam gerak tersebut, menyortir atau memilih gerak yang dianggap memenuhi tema, suasana dan cerita serta syarat estetika. Setelah berproses kreatif untuk mendapatkan gerak, kemudian gerak disimpan sebagai perbendaharaan gerak. Hasil dari eksplorasi gerak tersebut diperlihatkan pada Gambar 4 sampai 6.

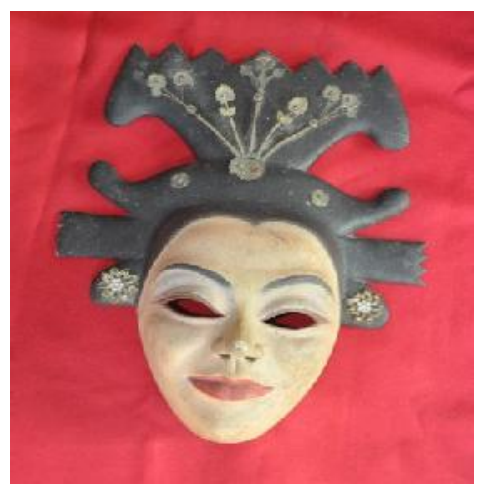

Gambar 3. Topeng Bidadari

Komposisi. Penataan komposisi ini dilakukan setelah melalui tahap eksplorasi dan evaluasi. Penataan komposisi yang dilakukan melalui proses bagian per bagian. Pada proses ini dimulailah untuk

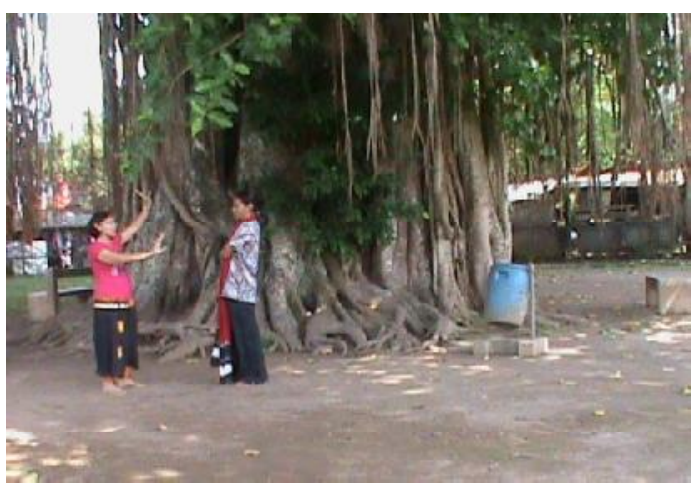

Gambar 4. Diskusi dengan Narasumber

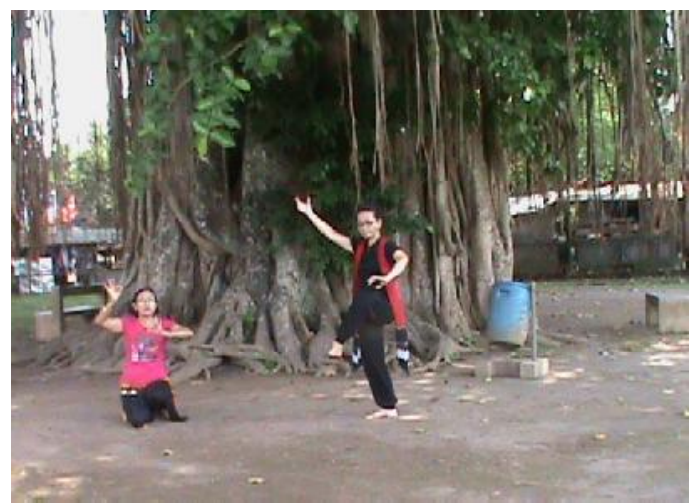

Gambar 5. Improvisasi dari Peneliti dan Anggota

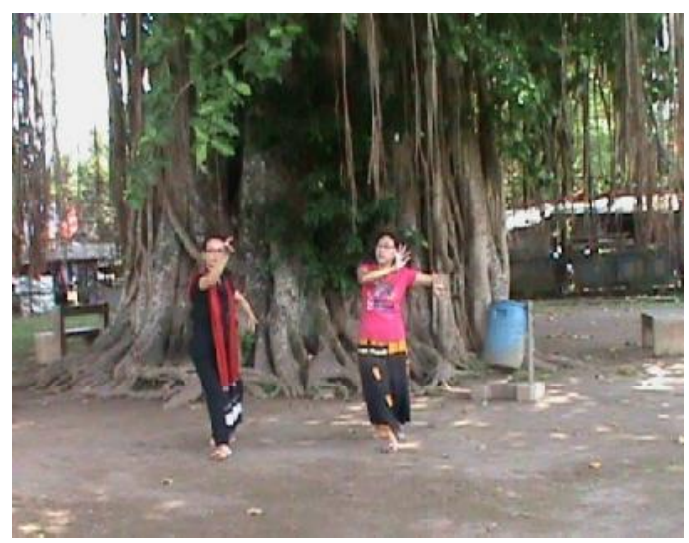

Gambar 6. Mencoba Berbagai Ragam Gerak

saling memadukan gerakan-gerakan yang telah dibuat, penyusunan adegan, serta desain lantai. Gerakan yang sudah 
didapat melalui tahap eksplorasi dan evaluasi mulai disatukan dan disusun menjadi suatu rentetan gerak yang saling berkesinambungan dan relevan berdasar pada konsep yang telah ditentukan. Komposisi atau susunan gerak yang berhasil dibuat dapat dilihat pada Gambar 7 sampai 12.

Evaluasi. Dalam tahap ini penata tari melakukan pemilihan ragam gerak yang sesuai atau memiliki relevansi dengan tema garapan. Pada proses evaluasi, gerak yang telah diciptakan dan dikumpulkan tersebut dipresentasikan kembali dengan mempertimbangkan saran dan masukan dari nara sumber.

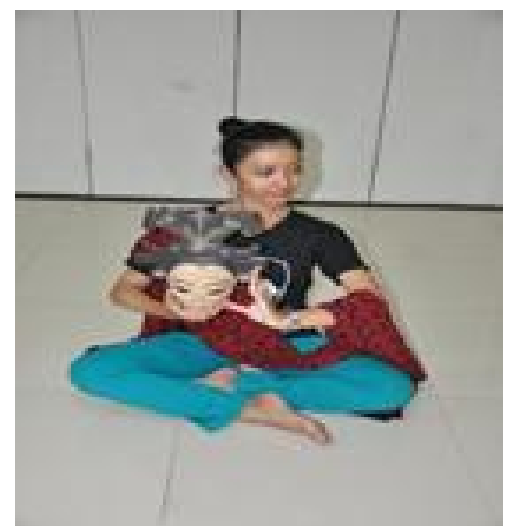

Gambar 7. Pose Awal Level Rendah

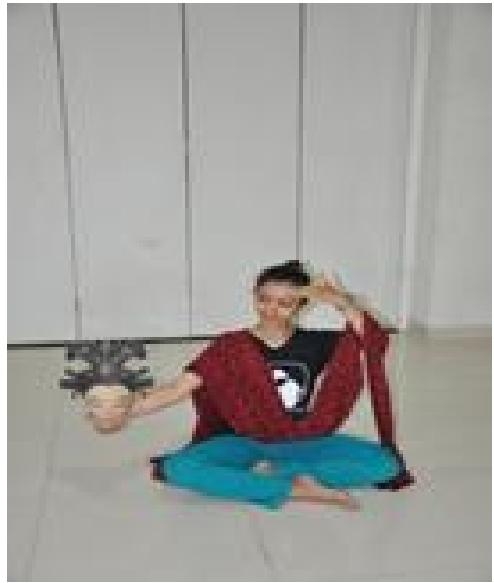

Gambar 8. Pose Level Rendah

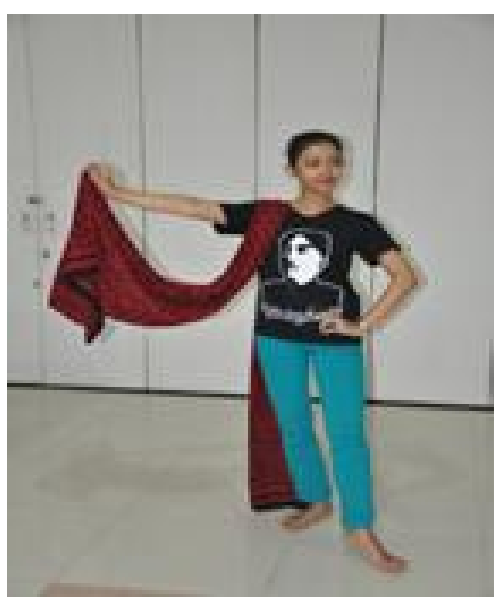

Gambar 9. Pose Sedang Disain A Simetris

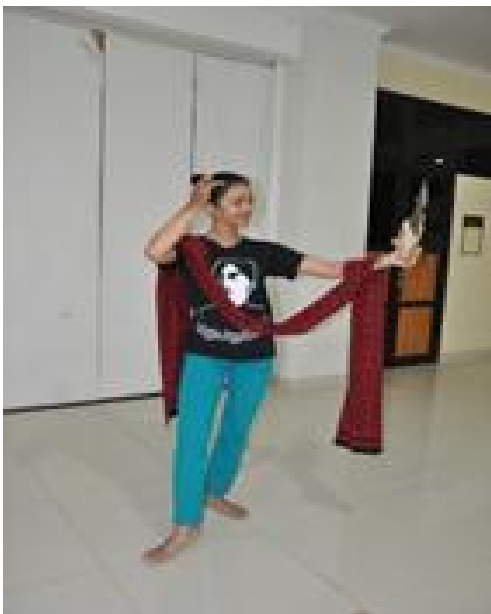

Gambar 10. Pose A Simetris Level Sedang

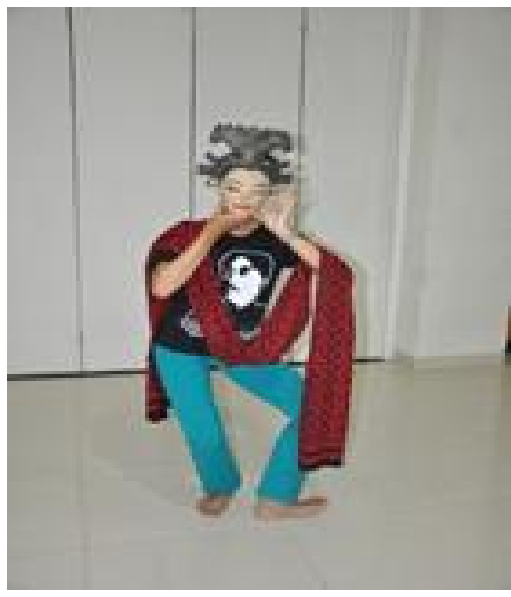

Gambar 11. Pose Mengenakan Topeng 


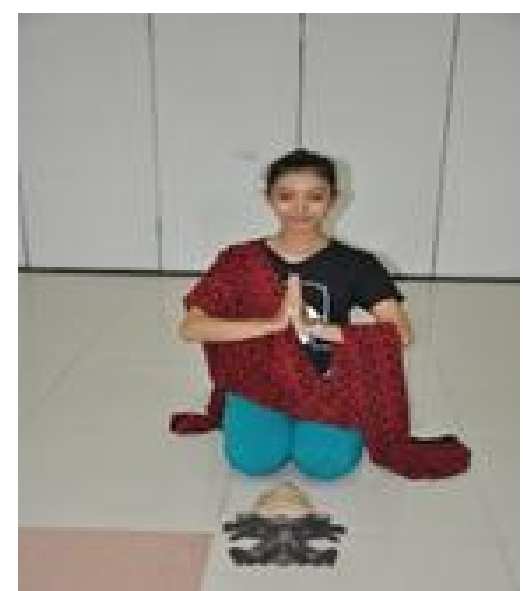

Gambar 12. Pose Sembah Penutup

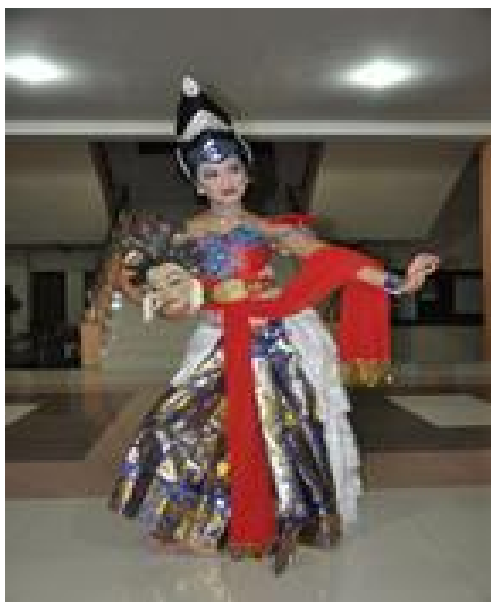

Gambar 13. Kostum dan Make Up Tari

Setelah terpilih ragam-ragam gerak yang sesuai, selanjutnya dilakukan perangkaian ragam gerak yang satu dengan yang lainnya, dengan diadakan penambahan-penambahan gerak sebagai penghubung dari ragam satu dengan ragam yang lain misalnya gerakan memutar, melompat. Evaluasi dilakukan bukan untuk gerakan saja, namun juga pada penempatan penari (pola lantai) harus tepat.

\section{SIMPULAN}

Dari serangkaian pembahasan hasil penelitian, beberapa hal dapat diambil kesimpulan sebagai berikut. (1) Deskripsi naratif dari wajah topeng bidadari dari Bali adalah wanita lemah lembut, halus budi pekertinya tetapi memiliki sifat tegas dan memegang teguh pendiriannya. Sedangkan wajah topeng Baladewa adalah ksatria perkasa yang gagah berani menegakkan kebenaran, adil, dan bijaksana. (2) Karya awal berupa pose ragam gerak tari, dan penggabungan gerak menjadi sebuah rangkaian gerak tari kreasi baru, telah dapat diwujudkan. Karya tari ini kami beri judul "Senandung Bidari", sebuah karya tari yang menggambarkan kegembiraan seorang putri. Kegembiraan seorang putri yang diawali dengan kegelisahan dan kebimbangan. Karya tari ini terinspirasi dari topeng Bali dan Madura. Konsep garapan dalam kaya ini berpijak pada tari gaya Yogyakarta dan tari daerah lain baik tradisi maupun kreasi tanpa menghilangkan identitas aslinya. Konsep cerita yang digarap dituangkan ke dalam konsep gerak yang telah disusun sehingga setiap gerakan yang dibuat memiliki makna. Karya tari ini menggunakan tipe dramatik.

\section{DAFTAR PUSTAKA}

Gall, M.D., Gall, J.P., \& Borg, W.R. 2003. Educational Research: An Introduction. ( $7^{\text {th }}$ Ed.). Boston: Alyn \& Bacon. Koentjoroningrat. 1990. Pengantar Ilnu Antropologi. Jakarta: Rineka Cipta. 